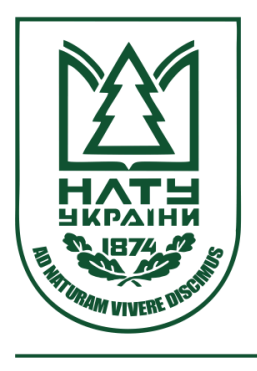

Науковий вісник НЛТУ України Scientific Bulletin of UNFU

http://nv.nltu.edu.ua

https://doi.org/10.15421/40281106

Article received 17.12.2018 p.

Article accepted 27.12.2018 p.

V. K. Zaika

vkzaika@ukr.net

удк 631*2:630*[161.037+176.322.6+177.952](477.84)

ю. С. Каленюк ${ }^{1}$ В. К. Зайка ${ }^{2}$

${ }^{1}$ Кременеиький лісотехнічний коледж, с. Білокриниия, Украӥна

${ }^{2}$ Національний лісотехнічний університет України, м. Львів, Украйна

\title{
ДІЕЛЕКТРИЧНІ ПОКАЗНИКИ ДУБА І ЛИПИ В ДЕРЕВОСТАНАХ СВІЖОЇ ГРАБОВОЇ ДІБРОВИ ЗАХІДНОГО ПОДІЛЛЯ
}

\begin{abstract}
Досліджено діелектричні показники дуба звичайного й липи дрібнолистої в деревостанах 41-100-річного віку свіжої грабової діброви Західного Поділля. Частка липи і дуба у складі цих деревостанів змінюється від поодиноких дерев до 10 одиниць. Встановлено, що у липи дрібнолистої середнє значення показників імпедансу на дослідних ділянках в середині вегетаційного періоду становить 5,0-9,4 кОм, а поляризаційної ємності - 1,58-3,86 нФ. У дуба звичайного вони, відповідно, змінювались в межах 5,5-9,7 кОм і 1,92-2,73 нФ. Високу інтенсивність процесів життєдіяльності у дуба встановлено в деревостанах, де він значно перевищує липу й інші деревні види за висотою за різної його частки у складі мішаних деревостанів. Істотне зниження процесів життєдіяльності дуба виявлено в чистих дубових і мішаних деревостанах, де дуб формує верхній ярус. Високий ступінь життєдіяльності у липи встановлено в деревостанах, де вона переважає дуба за часткою у їх складі та не відстає від нього в рості, а пригнічення життєвих процесів - за їі перебування у другому ярусі деревного намету. Діелектричні показники дуба характеризуються вищою кореляційною залежністю від лісівничо-таксаційних показників, ніж липи. Імпеданс і поляризаційна ємність дуба проявляє переважно значну і помірну тісноту кореляційного зв'язку з лісівничо-таксаційними показниками деревостанів, а липа - слабку, що вказує на її пригнічення з боку дубового намету. Загалом наші дослідження показали, що інтенсивність перебігу процесів життєдіяльності у дуба не залежить від його частки у складі деревостанів, а визначається ступенем його перевищення за висотою над іншими деревними видами.
\end{abstract}

Ключові слова: імпеданс; поляризаційна ємність; липа дрібнолиста; дуб звичайний; деревостан; процеси життєдіяльності.

Вступ. Високої продуктивності деревостани досягають за умови встановлення в процесі їх формування оптимальних взаємовідносин між деревними видами, що визначає інтенсивність життєдіяльності рослин в умовах фітоценозу. Ріст, як відомо, є складною функцією фізіолого-біохімічних процесів рослинного організму, який залежить як від зовнішніх, так і внутрішніх чинників (Terek \& Patsula, 2011). Інтегральними показниками життєдіяльності рослин є біоелектричні потенціали, імпеданс і поляризаційна ємність, які широко використовують для встановлення стану і стійкості деревних видів до абіотичних і біотичних чинників (Humeniuk, Zaika \& Bondarenko, 2014, 2012; Zaika, Krynytskyi \& Ivanytskyi, 2013; Zvarych, 2005; Krynytskyi \& Zaika, 1995; Maltcev, 1987; Mac Dougall, Maclean \& Thompson, 1988; Mac Dougall, Thompson \& Piene, 1987; Kolovskii, 1980), відбору високопродуктивних генотипів у популяціях та успадкування їх ознак потомством тощо (Krynytskyi, 1992, 1993).

Взаємовідносини дуба і граба в грабових дібровах Західного Поділля з використанням діелектричних показників показано в роботах I. Р. Гуменюка, В. К. Заїки i В. Д. Бондаренка (Humeniuk, Zaika \& Bondarenko, 2012, 2014). Вони встановили, що найкращі умови для росту і життєдіяльності граба звичайного складаються в чистих грабняках. Вже незначна участь дуба (1-3 одиниці) у складі деревостанів призводить до пригнічення життєвих процесів у граба внаслідок посилення фітоценотичної взаємодії. Водночас негативного впливу граба на дуба в деревостанах вони не встановили. Аналогічні закономірності під час дослідження взаємовпливів сосни і берези у процесі формування природних березовососнових 8-15-річних молодняків на покинутих сільськогосподарських землях Північно-західного Поділля встановили В. К. Заїка, Г. Т. Криницький і Р. С. Іваницький (Humeniuk, Zaika \& Bondarenko, 2012). В умовах Кременецького горбогір'я за діелектричними показниками показано взаємовплив модрини європейської i дуба звичайного в деревостанах різного віку та частки модрини у їх складі (Rybak \& Zaika, 2013).

Загалом дослідники встановили тісний зв'язок показників імпедансу і поляризаційної ємності з розташуванням дерев у межах лісового намету (Krynytskyi, 1992, 1993; Krynytskyi \& Zaika, 1995). У деревостанах найнижчими показниками імпедансу і найвищими поляризаційної ємності характеризуються панівні дерева 3 добре розвиненою кроною. У дерев нижчих класів росту показники імпедансу зростають, а поляризаційної ємності зменшуються. На зміну діелектричних показників дерев сосни, які ростуть у біогрупах відносно пооди-

\section{Інформація про авторів:}

Каленюк Юрій Степанович, викладач, кафедра лісівництва. Email: kaleniukyurii@gmail.com

Заїка Володимир Костянтинович, д-р біол. наук, професор, кафедра лісівництва. Email: vkzaika@ukr.net

Цитування за ДСТУ: Каленюк Ю. С., Заїка В. К. Діелектричні показники дуба і липи в деревостанах свіжої грабової діброви Західного Поділля. Науковий вісник НлтУ України. 2018, т. 28, № 11. С. 33-37.

Citation APA: Kalenyuk, Yu. S., \& Zaika, V. K. (2018). Dielectric indexes of oak and lime in the stands of the fresh hornbeam-oak forest of Western Podillya. Scientific Bulletin of UNFU, 28(11), 33-37. https://doi.org/10.15421/40281106 
ноко розташованих екземплярів, вказує також Ю. В. Зварич (Zvarych, 2005). В окремих роботах (Maltcev, 1987; Mac Dougall, Maclean \& Thompson, 1988) показано наявність досить високих кореляційних залежностей між поляризаційною ємністю і приростом, фітомасою хвої, ступенем пошкодження дерев ентомошкідниками.

Отже, діелектричні показники добре характеризують фізіологічний стан та інтенсивність перебігу процесів життєдіяльності у дерев під час формування деревостанів. Вони дають змогу на функціональному рівні встановити напруженість конкурентних взаємовідносин між деревними видами. Такі дослідження в деревостанах $\epsilon$ актуальними, оскільки дають змогу встановити їх оптимальний породний склад для формування високопродуктивних і біологічно стійких фітоценозів.

Об'єкт дослідження - дубові деревостани свіжої грабової діброви Західного Поділля з різною часткою у їх складі липи дрібнолистої.

Предмет дослідження - діелектричні показники прикамбіальних тканин лубу дерев дуба і липи в деревостанах різного породного складу.

Мета дослідження - встановити влив липи дрібнолистої на інтенсивність процесів життєдіяльності та фізіологічний стан дуба звичайного.

Дослідження проводили в дубових деревостанах за участю липи дрібнолистої віком 41-100 років, які ростуть в умовах свіжої грабової діброви Західного Поділля. Частка липи у їх складі становить від поодиноких дерев до 6-8 одиниць. Серед них переважають деревостани $з$ часткою липи 2-4 одиниці. Вони ростуть за II-I ${ }^{\mathrm{b}}$ класами бонітету (Zaika \& Kaleniuk, 2018). Вимірювання діелектричних показників (імпедансу і поляризаційної ємності) проводили на висоті стовбура 1,3 м 3 південної його сторони приладом Ф 4320 на частоті 1 кГц. Електроди вводили в луб дерев на висоті 1,3 м. Відстань між електродами становить 2 см (Kerimov \& Zaika, 2018).

Результати дослідження. Взаємовплив деревних видів у процесі формування деревостанів проявляється по-різному і відбувається, як на рівні кореневих систем, так і на рівні надземної частини лісового намету. Відомо, що липа дрібнолиста (Tilia cordata Mill.) негативно впливає на ріст і функціонування дуба, якщо вона не відстає від нього за інтенсивністю ростових процесів, або перевищує дуба звичайного (Quercus robur L.) за висотою (Zaika \& Kaleniuk, 2018). У наших дослідних деревостанах липа переважно відстає в рості від дуба за висотою на 3,7-46,1 \%. Найбільше відставання в рості липи від дуба виявлено на ділянках 10, 13, 16 і 17, а найменше - в деревостанах ділянок 4, 6, 8, 18, 19, 20. На ділянці 9 липа за висотою перевищує дуба. Абсолютна повнота деревостанів змінюється в межах 21,4$40,3 \mathrm{~m}^{2} /$ га, а запас деревини становить $172-487 \mathrm{~m}^{3} /$ га.

Значення діелектричних показників дерев липи і дуба наведено в табл. 1 .

Табл. 1. Діелектричні показники дуба і липи в дубових деревостанах з різним породним складом

\begin{tabular}{|c|c|c|c|c|c|c|c|}
\hline \multirow{2}{*}{$\begin{array}{c}\text { № } \\
\text { пр.пл. }\end{array}$} & \multirow{2}{*}{ Склад деревостану } & \multirow{2}{*}{$\begin{array}{l}\text { Вік, } \\
\text { років }\end{array}$} & \multirow{2}{*}{ Порода } & \multicolumn{2}{|c|}{ Імпеданс, кОм } & \multicolumn{2}{|c|}{ Поляризаційна ємність, нФ } \\
\hline & & & & $M^{ \pm m}$ & $V, \%$ & $M^{ \pm m}$ & $V, \%$ \\
\hline \begin{tabular}{|l|l}
1 \\
\end{tabular} & 2 & 3 & 4 & 5 & 6 & 7 & 8 \\
\hline \multicolumn{8}{|c|}{ Липень 2014 р. } \\
\hline 1 & 10Лпд+Бп & 45 & Лпд & $6,1^{ \pm 0,2}$ & 20,8 & $1,65^{ \pm 0,04}$ & 17,6 \\
\hline \multirow{2}{*}{2} & \multirow{2}{*}{ 8Лпд1Мдє1Гз+ДзКлгЧш } & \multirow{2}{*}{51} & Д3 & $5,8^{ \pm 0,2}$ & 11,4 & $3,13^{ \pm 0,09}$ & 12,4 \\
\hline & & & Лпд & $5,3^{ \pm 0,3}$ & 33,8 & $3,83^{ \pm 0,10}$ & 56,9 \\
\hline \multirow{2}{*}{3} & \multirow{2}{*}{ 6Лпд2Ясз1Дз1Бп+Гз, Взг, Клг } & \multirow{2}{*}{45} & Д3 & $6,9^{ \pm 0,2}$ & 21,4 & $2,15^{ \pm 0,06}$ & 23,4 \\
\hline & & & Лпд & $5,2^{ \pm 0,3}$ & 25,2 & $3,74^{ \pm 0,10}$ & 27,1 \\
\hline \multirow{2}{*}{4} & \multirow{2}{*}{ 4Лпд2Ясз2Чш1Дз1Клг+ДчГз } & \multirow{2}{*}{55} & Д3 & $6,2^{ \pm 0,3}$ & 22,9 & $2,22^{ \pm 0,08}$ & 26,2 \\
\hline & & & Лпд & $5,0^{ \pm 0,4}$ & 29,4 & $3,86^{ \pm 0,12}$ & 32,4 \\
\hline \multirow{2}{*}{5} & \multirow{2}{*}{ 4Дз3Клг2Лпд1Бп+ГзКляВзг } & \multirow{2}{*}{50} & Д3 & $6,5^{ \pm 0,4}$ & 25,7 & $2,09^{ \pm 0,09}$ & 26,7 \\
\hline & & & Лпд & $5,9^{ \pm 0,5}$ & 29,3 & $3,24^{ \pm 0,11}$ & 32,1 \\
\hline \multirow{2}{*}{6} & \multirow{2}{*}{ 5Лпд3Дз2Гз+Кля } & \multirow{2}{*}{56} & Д3 & $7,6^{ \pm 0,3}$ & 28,6 & $2,01^{ \pm 0,08}$ & 26,4 \\
\hline & & & Лпд & $5,1^{ \pm 0,3}$ & 32,4 & $3,67^{ \pm 0,25}$ & 42,3 \\
\hline \multirow{2}{*}{7} & \multirow{2}{*}{ 4Лпд3Дз2Гз1Чш } & \multirow{2}{*}{56} & Д3 & $6,2^{ \pm 0,3}$ & 24,0 & $2,61^{ \pm 0,16}$ & 26,2 \\
\hline & & & Лпд & $5,9^{ \pm 0,3}$ & 29,3 & $3,07^{ \pm 0,26}$ & 54,1 \\
\hline 8 & 5Дз4Лпд1Гз +ЯсзК КгЧш & 55 & Д3 & $7,7^{ \pm 0,3}$ & 23,6 & $1,75^{ \pm 0,06}$ & 24,2 \\
\hline & 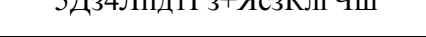 & $J J$ & Лпд & $5,6^{ \pm 0,2}$ & 25,8 & $3,29^{ \pm 0,23}$ & 55,6 \\
\hline 9 & 5 Пз4Ппп1Г2 & 58 & Д3 & $7,9^{ \pm 0,3}$ & 19,6 & $1,68^{ \pm 0,08}$ & 24,1 \\
\hline 9 & эдз4Лпд11 3 & 58 & Лпд & $6,2^{ \pm 0,2}$ & 22,1 & $2,96^{ \pm 0,18}$ & 29,6 \\
\hline 10 & 5Дз3Лпл1Кпя1Гз +Яс3 & 41 & Д3 & $7,9^{ \pm 0,4}$ & 30,7 & $1,86^{ \pm 0,09}$ & 29,4 \\
\hline & & 41 & Лпд & $5,7^{ \pm 0,3}$ & 28,1 & $3,34^{ \pm 0,31}$ & 51,4 \\
\hline 11 & 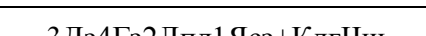 & 50 & Дз & $7,1^{ \pm 0,3}$ & 24,1 & $1,93^{ \pm 0,08}$ & 25,8 \\
\hline 11 & зД341 з2ЛПдІ Яс3+КЛГЧШ & 59 & Лпд & $6,7^{ \pm 0,5}$ & 38,3 & $3,04^{ \pm 0,28}$ & 47,0 \\
\hline 12 & 10Дз+Бп & 44 & Д3 & $9,1^{ \pm 0,4}$ & 36,7 & $1,54^{ \pm 0,09}$ & 39,8 \\
\hline 13 & 9Дз1Оc+ЛплГЗ Чшш & 55 & Д3 & $7,5^{ \pm 0,3}$ & 31,3 & $1,99^{ \pm 0,08}$ & 28,8 \\
\hline & & $\mathrm{JJ}$ & Лпд & $8,9^{ \pm 0,4}$ & 39,4 & $1,62^{ \pm 0,09}$ & 36,3 \\
\hline 14 & 5Дз2 Дпп1К & 63 & Д3 & $8,1^{ \pm 0,3}$ & 23,0 & $1,73^{ \pm 0,06}$ & 24,7 \\
\hline & 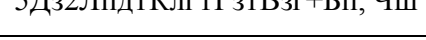 & 05 & Лпд & $7,0^{ \pm 0,2}$ & 18,6 & $1,72^{ \pm 0,08}$ & 26,6 \\
\hline 15 & 6Дз3Лпл1Гз+Oc & 75 & Д3 & $5,9^{ \pm 0,2}$ & 22,3 & $1,92^{ \pm 0,05}$ & 23,3 \\
\hline & & 15 & Лпд & $5,6^{ \pm 0,5}$ & 29,4 & $3,27^{ \pm 0,24}$ & 31,3 \\
\hline 16 & 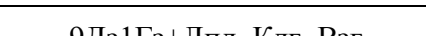 & 64 & Д3 & $7,9^{ \pm 0,3}$ & 26,3 & $1,82^{ \pm 0,07}$ & 24,1 \\
\hline 10 & УДЗ З з Лпд, Клг, Взг & 04 & Лпд & $8,8^{ \pm 0,5}$ & 32,1 & $1,66^{ \pm 0,12}$ & 33,1 \\
\hline 17 & $6 \frac{10 Д 3}{6 Г з 2 Л п д 1 К л г 1 Ч ш+К л я Б к л В з г ~}$ & 77 & $\frac{\text { Дз }}{\text { Лпд }}$ & $\frac{9,7^{ \pm 0,8}}{9,4^{ \pm 0,9}}$ & $\frac{50,4}{44,2}$ & $\frac{1,92^{ \pm 0,10}}{1,58^{ \pm 0,11}}$ & $\frac{32,7}{38,9}$ \\
\hline 18 & ( & 100 & Д3 & $6,9^{ \pm 0,2}$ & 20,0 & $2,37^{ \pm 0,08}$ & 21,2 \\
\hline 18 & бЛПд2Д321 3 & 100 & Лпд & $5,8^{ \pm 0,2}$ & 24,7 & $2,69^{ \pm 0,18}$ & 43,5 \\
\hline 10 & & 90 & Д3 & $6,9^{ \pm 0,3}$ & 32,1 & $2,63^{ \pm 0,11}$ & 27,9 \\
\hline 19 & эДЗ3ЛЛпд21 з+КлГ & 90 & Лпд & $5,8^{ \pm 0,3}$ & 32,6 & $3,10^{ \pm 0,26}$ & 49,1 \\
\hline 20 & 2Дз5Гз2Лпд1Ясз+Клг, Взг & 92 & Д3 & $7,4^{ \pm 0,3}$ & 23,8 & $2,20^{ \pm 0,07}$ & 22,4 \\
\hline
\end{tabular}




\begin{tabular}{|c|c|c|c|c|c|c|c|}
\hline 1 & 2 & 3 & 4 & 5 & 6 & 7 & 8 \\
\hline & & & Лпд & $6,6^{ \pm 0,3}$ & 28,6 & $2,06^{ \pm 0,12}$ & 31,5 \\
\hline \multirow{2}{*}{21} & \multirow{2}{*}{ 5Дз3Гз2Лпд } & \multirow{2}{*}{96} & Д3 & $6,1^{ \pm 0,3}$ & 24,3 & $2,68^{ \pm 0,12}$ & 25,4 \\
\hline & & & Лпд & $5,0^{ \pm 0,2}$ & 22,0 & $3,70^{ \pm 0,29}$ & 38,1 \\
\hline \multirow{2}{*}{22} & \multirow{2}{*}{ 9Дз1Гз+ЛпдЯсз } & \multirow{2}{*}{89} & Д3 & $5,5^{ \pm 0,4}$ & 26,1 & $2,73^{ \pm 0,10}$ & 24,4 \\
\hline & & & Лпд & $6,0^{ \pm 0,3}$ & 24,1 & $3,42^{ \pm 0,18}$ & 27,9 \\
\hline \multicolumn{8}{|c|}{ Липень 2015 р. } \\
\hline 1 & 10Лпд+Бп & 45 & Лпд & $6,9^{ \pm 0,3}$ & 23,8 & $2,08^{ \pm 0,12}$ & 39,3 \\
\hline \multirow{2}{*}{3} & \multirow{2}{*}{ 6Лпд2Ясз1Дз1Бп+Гз, Взг, Клг } & \multirow{2}{*}{45} & Д3 & $9,5^{ \pm 1,3}$ & 54,7 & $1,73^{ \pm 0,36}$ & 46,2 \\
\hline & & & Лпд & $6,6^{ \pm 0,3}$ & 22,4 & $2,44^{ \pm 0,20}$ & 43,2 \\
\hline \multirow{2}{*}{6} & \multirow{2}{*}{ 5Лпд3Дз2Гз+Кля } & \multirow{2}{*}{56} & Д3 & $9,0^{ \pm 0,4}$ & 26,9 & $1,68^{ \pm 0,06}$ & 21,3 \\
\hline & & & Лпд & $5,8^{ \pm 0,4}$ & 31,0 & $3,24^{ \pm 0,32}$ & 49,1 \\
\hline \multirow{2}{*}{8} & \multirow{2}{*}{ 5Дз4Лпд1Гз+ЯсзКлгЧш } & \multirow{2}{*}{55} & Д3 & $8,4^{ \pm 0,3}$ & 22,1 & $1,84^{ \pm 0,12}$ & 35,1 \\
\hline & & & Лпд & $6,7^{ \pm 0,4}$ & 28,7 & $2,55^{ \pm 0,22}$ & 45,2 \\
\hline \multirow{2}{*}{9} & \multirow{2}{*}{ 5Дз4Лпд1Гз } & \multirow{2}{*}{58} & Д3 & $8,0^{ \pm 0,4}$ & 21,7 & $1,80^{ \pm 0,09}$ & 23,8 \\
\hline & & & Лпд & $6,9^{ \pm 0,4}$ & 30,3 & $2,30^{ \pm 0,19}$ & 40,5 \\
\hline \multirow{2}{*}{10} & \multirow{2}{*}{ 5Дз3Лпд1Кля1Гз+Ясз } & \multirow{2}{*}{44} & Д3 & $9,9^{ \pm 0,8}$ & 44,2 & $1,64^{ \pm 0,08}$ & 26,6 \\
\hline & & & Лпд & $7,4^{ \pm 0,3}$ & 23,5 & $2,29^{ \pm 0,18}$ & 45,0 \\
\hline 12 & 10Дз+Бп & 45 & Д3 & $9,6^{ \pm 0,3}$ & 27,8 & $1,78^{ \pm 0,09}$ & 35,5 \\
\hline \multirow{2}{*}{13} & \multirow{2}{*}{ 9Дз1Ос+ЛпдГзЧш } & \multirow{2}{*}{55} & Д3 & $7,9^{ \pm 0,3}$ & 22,8 & $1,87^{ \pm 0,07}$ & 22,3 \\
\hline & & & Лпд & $9,2^{ \pm 0,5}$ & 41,2 & $1,58^{ \pm 0,09}$ & 38,9 \\
\hline \multirow{2}{*}{14} & \multirow{2}{*}{ 5Дз2Лпд1Клг1Гз1Взг+Бп, Чш } & \multirow{2}{*}{63} & Д3 & $8,0^{ \pm 0,4}$ & 21,7 & $1,80^{ \pm 0,09}$ & 23,8 \\
\hline & & & Лпд & $6,9^{ \pm 0,4}$ & 30,3 & $2,50^{ \pm 0,19}$ & 40,5 \\
\hline \multirow{2}{*}{16} & \multirow{2}{*}{ 9Дз1Гз+Лпд, Клг, Взг } & \multirow{2}{*}{64} & Д3 & $8,3^{ \pm 0,3}$ & 22,3 & $1,79^{ \pm 0,08}$ & 26,1 \\
\hline & & & Лпд & $7,5^{ \pm 0,4}$ & 27,1 & $2,18^{ \pm 0,11}$ & 30,3 \\
\hline \multirow{2}{*}{20} & 2Дз5Гз2 Лпл1Яс3+Клг, Взг & 02 & Д3 & $8,2^{ \pm 0,6}$ & 39,6 & $2,12^{ \pm 0,08}$ & 20,8 \\
\hline & 2ДзЈІ з2ЛПдІ Ясз+Клг, Взг & 92 & Лпд & $6,0^{ \pm 0,2}$ & 24,5 & $2,60^{ \pm 0,15}$ & 33,7 \\
\hline
\end{tabular}

Згідно $з$ даними табл. 1, у липи дрібнолистої показники імпедансу в середині вегетаційного періоду становили 5,0-9,4 кОм, а поляризаційної ємності- 1,583,86 нФ. У дуба звичайного вони, відповідно, змінювались в межах 5,5-9,7 кОм і 1,92-2,73 нФ. Найвищу інтенсивність життєдіяльності дуба звичайного встановлено в деревостанах на ділянках 2, 4, 7, 15, 21, 22. Показники імпедансу прикамбіальних тканин дуба в цих деревостанах становлять 5,5-6,2 кОм, а поляризаційної ємності - 1,92-3,13 нФ. Це різні за складом і віком деревостани. У середньовікових деревостанів на пробних площах 2, 4, 7 частка липи у їх складі становить 48 одиниці, а дуба коливається від поодиноких дерев до 3-х одиниць. У пристиглих і стиглих деревостанах на ділянках 15, 21 і 22 частка дуба становить 5-9 одиниць. Отже, інтенсивність перебігу процесів життєдіяльності у дуба не залежить від його частки у складі деревостанів. Об'єднує всі ці деревостани показник перевищення висоти дуба над іншими деревними видами, яке тільки на ділянці 4 становить 5,4 \%, а на інших - 15,8-31,6\%. Істотне зниження процесів життедіяльності дуба виявлено в деревостанах на ділянках 12 і 17. Середні показники імпедансу у дуба тут зросли до 9,1-9,7 кОм, а поляризаційна ємність знизилась до 1,54-1,92 нФ. Треба зазначити, що на ділянці 12 сформувався чистий дубовий деревостан 3 незначною домішкою берези повислої, а на ділянці 17 дуб утворює верхній ярус, а граб, липа, клени гостролистий і явір, бук, в'яз, черешня ростуть у другому ярусі. Встановлене зниження життєдіяльності дуба в чистих дубових, або близьких до них деревостанах $є$ наслідком посилення внутрішньо-конкурентної боротьби.

Для встановлення взаємовпливу на життєдіяльність деревних видів дослідили також діелектричні показники у липи серцелистої. У неї показники імпедансу змінюються в межах 5,0-9,4 кОм, а поляризаційної ємності - від 1,58 до 3,86 нФ. Високий ступінь життєдіяльності липи виявлено в деревостанах на пробних площах $2,3,4,6,21$, де показники імпедансу у неї становлять 5,0-5,3 кОм, а поляризаційної ємності 3,67-3,86 нФ (див. табл. 1). У цих деревостанах липа зазвичай переважає дуба за часткою, яка на ділянка 2, 3, 4, 6 змінюється в межах 4-8 одиниць. На ділянці 21 з складом деревостану 5Дз3Гз2Лпд у віці 96 років склались сприятливі умови для функціонування обох деревних видів. Тут дуб і липа сформували верхній ярус за відносно незначної кількості дерев, а саме по 60 екземплярів кожного виду. Несприятливі умови для росту і функціонування липи склались на ділянках 13, 16 і 17. Показники імпедансу у неї тут зросли до 8,8-9,4 кОм, а поляризаційної ємності знизились до 1,58-1,66 нФ. Причиною пригнічення життєдіяльності липи в цих деревостанах є іï істотне (на 40,6-48,3\%) відставання в рості від дуба. Липа в цих деревостанах перебуває у дуже пригніченому стані і нездатна повноцінно виконувати позитивні функції для дубового деревостану. У переважної кількості деревостанів склались сприятливі взаємовідносини між дубом і липою.

В окремих роботах показано зв'язок електрофізіологічних показників з біометричними показниками дерев (Maltcev, 1987; Mac Dougall, Maclean \& Thompson, 1988). Однак немає даних щодо впливу лісівничо-таксаційних показників деревостанів на електрофізіологічну активність. Наші дослідження таких кореляційних залежностей наведено в табл. 2. Згідно 3 даними ієї таблиці, діелектричні показники дуба характеризуються вищою кореляційною залежністю від лісівничо-таксаційних показників, ніж липи. Так, імпеданс і поляризаційна ємність дуба проявляє значну тісноту кореляційного зв'язку з густотою дерев дуба і загальною деревостану, з діаметром і висотою дерев дуба та з висотою дерев липи. 3 часткою дуба у складі деревостанів його діелектричні показники характеризуються помірною залежністю, а з часткою липи, густотою липи і повнотою деревостанів - слабкою. На функціонування липи найбільшою мірою впливає частка дуба у складі деревостанів і його густота. Коефіцієнт кореляції між часткою дуба і імпедансом прикамбіальних тканин липи становить 0,526 , а 3 поляризаційною ємністю - -0,383. 3 густотою дуба та діелектричними показниками липи 
кореляційний зв'язок знизився до помірного, а з іншими показниками деревостанів - до слабкого.

Табл. 2. Кореляційний зв'язок між лісівничо-таксаційними та діелектричними показниками дерев дуба і липи в деревостанах

\begin{tabular}{|c|c|c|c|c|}
\hline \multirow{2}{*}{ Показник } & \multicolumn{2}{|c|}{ Дуб звичайний } & \multicolumn{2}{|l}{ Липа дрібнолиста } \\
\cline { 2 - 5 } & $\begin{array}{c}\text { імпе- } \\
\text { данс }\end{array}$ & $\begin{array}{c}\text { поляриза- } \\
\text { ційна } \\
\text { ємність }\end{array}$ & $\begin{array}{c}\text { імпе- } \\
\text { данс }\end{array}$ & $\begin{array}{c}\text { поляриза- } \\
\text { ційна } \\
\text { ємність }\end{array}$ \\
\hline Частка в деревостані: & & & & \\
\hline дуба & 0,492 & $-0,403$ & 0,526 & $-0,383$ \\
\hline липи & $-0,164$ & 0,304 & $-0,444$ & 0,061 \\
\hline Густота, екз./га: & & & & \\
\hline дуба & 0,696 & $-0,645$ & 0,328 & $-0,320$ \\
\hline липи & 0,048 & 0,041 & $-0,229$ & $-0,103$ \\
\hline деревостану & 0,529 & $-0,410$ & 0,161 & $-0,151$ \\
\hline Діаметр, см: & & & & \\
\hline дуба & $-0,565$ & 0,714 & & \\
\hline липи & & & $-0,275$ & 0,087 \\
\hline Висота, м: & & & & \\
\hline дуба & $-0,576$ & 0,642 & $-0,004$ & $-0,020$ \\
\hline липи & $-0,592$ & 0,522 & $-0,342$ & 0,225 \\
\hline Повнота деревостану, & $-0,123$ & 0,345 & $-0,084$ & $-0,061$ \\
\hline м/га & & & & \\
\hline
\end{tabular}

\section{Висновки}

1. Високу інтенсивність процесів життєдіяльності у дуба встановлено в деревостанах, де він значно перевищує липу й інші деревні види за висотою за різної його частки у складі мішаних деревостанів. Істотне зниження процесів життєдіяльності дуба виявлено в чистих дубових $\mathrm{i}$ мішаних деревостанах, де дуб формує верхній ярус.

2. Високий ступінь життєдіяльності у липи виявлено в деревостанах, де вона переважає дуба за часткою у їх складі та не відстає від нього в рості, а пригнічення життєвих процесів - при ії̈ передуванні у другому ярусі деревного намету.

3. Діелектричні показники дуба характеризуються вищою кореляційною залежністю від лісівничо-таксаційних показників, ніж липи. Імпеданс і поляризаційна ємність дуба проявляє переважно значну і помірну тісноту кореляційного зв'язку з лісівничо-таксаційними показниками деревостанів, а липа - слабку, що вказує на іiі пригнічення зі сторони дубового намету.

\section{Перелік використаних джерел}

Humeniuk, I. R., Zaika, V. K., \& Bondarenko, V. D. (2012). Stan hraba zvychainoho v lisostanakh zapovidnyka "Medobory". Scientific reports of the National University of Bioresources and Natural Resources of Ukraine. Series: Arboriculture and Ornamental Horticulture, 171(1), 57-60. [In Ukrainian].

Humeniuk, I. R., Zaika, V. K., \& Bondarenko, V. D. (2014). Dielektrychni pokaznyky hraba i duba $\mathrm{v}$ hrabovo-dubovykh derevos- tanakh Zakhidnoho Podillia. Prospects for the development of forestry and gardening: materials of the International Scientific and Practical Conference. Uman, 108-110. [In Ukrainian].

Kerimov, E. I., \& Zaika, V. K. (2018). Dielektrychni pokaznyky derevnykh vydiv u derevostanakh za uchastiu modryny yevropeiskoi. Scientific Bulletin of UNFU, 28(8), 23-27. [In Ukrainian].

Kolovskii, R. A. (1980). Bioelektricheskie potentcialy drevesnykh rastenii. Novosibirsk: Izd-vo "Nuka", 176 p. [In Russian].

Krynytskyi, H. T. (1992). Pro metodyku vykorystannia elektrofiziolohichnykh pokaznykiv dlia vyznachennia zhyttiezdatnosti derevnykh roslyn. Proceedings of the Forestry Academy of Sciences of Ukraine, 23, 3-10. [In Ukrainian].

Krynytskyi, H. T. (1993). Morfofiziolohichni osnovy selektsii derevnykh porid. Abstract of Doctoral Dissertation for Biology Sciences (06.03.01 - Forest Crops and Phytomelioration), (03.00.12 Plant physiology). Kyiv, 46 p. [In Ukrainian].

Krynytskyi, H. T., \& Zaika, V. K. (1995). Vplyv osoblyvostei formuvannia molodykh pivsibsovykh nasadzhen sosny zvychainoi na bioelektrychnu aktyvnist derev. Scientific Bulletin of UkrSFU. Natural research on Roztocze, 4, 153-160. [In Ukrainian].

Mac Dougall, R., Maclean, D. A., \& Thompson, R. G. (1988). The use of electrical capacitance to determine growth and vigor of spruce and fir trees and stands in New Brunswicch. Can. J. Forest Res, 17(5), 587-594.

Mac Dougall, R., Thompson, R. G., \& Piene, H. (1987). Stem electrical capacitance and resistace measurements as relanend to total foliar biomass of balsam fir trees. Can. J. Forest Res, 17(9), 10701074.

Maltcev, G. A. (1987). Otcenka zhiznesposobnosti sosny elektrofiziologicheskim i vizualnym metodom. Materials of the 10th All-Union Scientific Conference of Students and Researchers of the Institute of Forestry and Mechanization of Forestry, (pp. 195-198), April 1, Pushkino. Moscow, 264 p. [In Russian].

Rybak, Yu. L., \& Zaika, V. K. (2013). Zmina elektrofiziolohichnoi aktyvnosti u derev sosny zvychainoi, urazhenykh shiutte zvychainym. Scientific Bulletin of UNFU, 23(02), 90-96. [In Ukrainian].

Terek, O. I., \& Patsula, O. I. (2011). Rist i rozvytok roslyn: navchalnyi posibnyk. Lviv: LNU imeni Ivana Franka, 328 p. [In Ukrainian].

Zaika, V. K., \& Kaleniuk, Yu. S. (2018). Rist i formuvannia dubovykh derevostaniv za uchastiu lypy dribnolystoi v umovakh svizhoi hrabovoi dibrovy Zakhidnoho Podillia. Proceedings of the Forestry Academy of Sciences of Ukraine, 17, 37-45. [In Ukrainian].

Zaika, V. K., Krynytskyi, H. T., \& Ivanytskyi, R. S. (2013). Pryrodne zalisennia ta lisivnycho-ekolohichni i morfofiziolohichni osoblyvosti formuvannia lisostaniv na pokynutykh silskohospodarskykh zemliakh Pivnichno-zakhidnoho Podillia. Proceedings of the Forestry Academy of Sciences of Ukraine, 11, 41-50. [In Ukrainian].

Zvarych, Yu. V. (2005). Vplyv prostorovoi struktury derevostaniv na zhyttievist derev sosny zvychainoi. Scientific fundamentals of productivity and biological sustainability of forest and urban ecosystems: materials of the 55th International Scientific and Technical Conference of Faculty Members, Researchers, Doctoral Students and Ph.D. Students of the National Academy of Sciences of Ukraine, (pp. 31-33), May 19-21. Lviv, 360 p. [In Ukrainian].

ю. С. Каленюк', В. К. Заика ${ }^{2}$

${ }^{l}$ Кременецкий лесотехнический колледж, с. Белокриница, Украина ${ }^{2}$ Наичональный лесотехнический университет Украины, г. Львов, Украина

\section{ДИЭЛЕКТРИЧЕСКИЕ ПОКАЗАТЕЛИ ДУБА И ЛИПЫ В ДРЕВОСТОЯХ СВЕЖЕЙ ГРАБОВОЙ ДУБРАВЫ ЗАПАДНОГО ПОДОЛЬЯ}

Исследованы диэлектрические показатели дуба черешчатого и липы мелколистной в древостоях 41-100-летнего возраста свежей грабовой дубравы Западного Подолья. Долевое участие липы и дуба в составе этих древостоев колеблется от единичных деревьев до 10 единиц. Установлено, что у липы мелколистной среднее значение показателей импеданса на опытных участках в середине вегетационного периода составляют 5,0-9,4 кОм, а поляризационной емкости - 1,58-3,86 нФ. У дуба черешчатого они, соответственно, менялись в пределах 5,5-9,7 кОм и 1,92-2,73 нФ. Высокая интенсивность процессов жизнедеятельности у дуба установлена в древостоях с разным его долевым участием в составе, где он значительно превышает липу и другие древесные виды по высоте. Существенное снижение процессов жизнедеятельности дуба обнаружено в чистых дубовых и смешанных древостоях, где дуб формирует господствующий ярус. Высокая степень жизнедеятельности у липы установлена в древостоях, где она преобладает дуба по долевому участию в их составе и не отстает от него в росте, а 
угнетение жизненных процессов - при ее нахождении во втором ярусе древостоя. Диэлектрические показатели дуба характеризуются более высокой корреляционной зависимостью от лесоводственно-таксационных показателей древостоев, чем липы. Импеданс и поляризационная емкость дуба проявляет преимущественно значительную и умеренную тесноту корреляционной связи с лесоводственно-таксационными показателями древостоев, а липа - слабую, что указывает на ее подавление со стороны дубового яруса. В общем, установлено, что интенсивность прохождения процессов жизнедеятельности у дуба не зависит от его долевого участия в составе древостоев, а определяется степенью его превышения по высоте над другими древесными видами.

Ключевые слова: импеданс; поляризационная емкость; липа мелколистная; дуб черешчатый; древостой; процессы жизнедеятельности.

Yu. S. Kalenyuk ${ }^{1}$, V. K. Zaika ${ }^{2}$

${ }^{1}$ Kremenetskiy Forestry College, Bilokrynytsya, Ukraine

${ }^{2}$ Ukrainian National Forestry University, Lviv, Ukraine

\section{DIELECTRIC INDEXES OF OAK AND LIME IN THE STANDS OF THE FRESH HORNBEAM-OAK FOREST OF WESTERN PODILLYA}

To investigate the relationship between tree species during the formation of forest stands, electrophysiological methods, which integrally characterize the intensity of plant life, have been used. The dielectric indexes of common oak and small-leaved lime in the 41-100-year-old stands of the fresh hornbeam-oak forest of Western Podillya were investigated. The shares of lime and oak in the composition of these stands vary from single trees to 10 units. The average value of the impedance indexes in small-leaved lime at the study sites in the middle of the growing season was found to be 5.0-9.4 k $\Omega$, and the polarization capacity to be $1.58-3.86 \mathrm{nF}$. Concerning common oak, they ranged within $5.5-9.7 \mathrm{k} \Omega$ and $1.92-2.73 \mathrm{nF}$ respectively. The high intensity of the life processes of oak was observed in the stands with its various shares in their composition where it significantly exceeds lime and other tree species in height. Significant decline in the life activities of oak is found in pure oak stands and mixed stands, where oak forms the upper storey. The high level of life activities in lime is found in the stands where oak dominates in the composition and does not lag behind it in growth, while the inhibition of lime life processes occurs when lime is in the second storey of the stand canopy. Dielectric indexes of oak are characterized by a higher, as compared to lime, correlation dependence on forest-mensuration indexes of stands. The impedance and polarization capacity of oak reveal predominantly significant and moderate correlation relationship with the density, diameter and height of oak trees and the total stand density as well as the height of the lime trees. The functioning of lime is most affected by the proportion of oak trees in the composition of the stand as well as the density of the oak trees. The correlation coefficient between the proportion of oak and the impedance of precambium issue of lime is 0.526 , and with the polarization capacity --0.338 . With increasing the density of oak trees and dielectric indexes of lime, the correlation relationship decreased to moderate, and with other indicators of the stands - to weak, indicating lime suppression on the part of the oak canopy. In general, our studies have shown that the intensity of oak life process does not depend on its share in the composition of the stands, but is determined by the degree of exceeding its height over other tree species. In the vast majority of stands, there is a favourable relationship between woody species for the life of oak and lime.

Keywords: impedance; polarization capacity; small-leaved lime; common oak; forest stand; life processes. 